\title{
血小板中に存在する腫痬細胞増殖因子について
}

\author{
新津洋司郎* 越田 吉一 $*$ 小野寺義光* 茂木 良弘* \\ 石垣 聖史* 古川 勝久* 高後 裕* 漆崎 一朗*
}

\section{Growth promoting factors of human platelet for tumor cells}

\author{
Yoshiro NIITSU*, Yoshikazu KOSHIDA*, Yoshimitsu ONODERA*, \\ Yoshihiro MOGI*, Seiji ISHIGAKI*, Katsuhisa KOGAWA*, \\ Yutaka KOHGO and Ichiro URUSHIZAKI*
}

Key words: Platelet derived growth factor (PDGF), acidic factor, tumor cell growth, purification, characterization

Three growth factors (acidic, neutral and basic) were partially purified from platelet lysate by DE 52 cellulose chromatography. The basic factor was proved to be identical to PDGF hitherto reported. The growth promoting activity of these three factors for variouse cell lines was studied in vitro.

Basic factor (PDGF) promoted growth of fibroblast (Swiss 3 T 3, SV 3 T 3) as has been described previouly, but had relatively less activity of growth promotion to malignant tumor cell lines ( $\mathrm{K} \mathrm{562,} \mathrm{HeLa} \mathrm{and} \mathrm{RPMI} \mathrm{4788).}$

On contrast, acidic factor strongly stimulated the proliferation of tumor cells and, to less extent, of fibroblasts.

Malignant cells ( $\mathrm{K}$ 562) were synchronized to pre $\mathrm{S}$ phase by addition of excess of thymidine and hydroxyurea, and thus synchronized cells were also proved to be more sensitive to acidic factor than to PDGF, indicating that the sensitivity is not related to cell cycle.

* 札幌医科大学第四内科 [T060 札幌市中央区南 1 条西16丁目], Department of Internal Medicine (Section 4), Sapporo Medical College, Sapporo, Japan. [1984年6 月13日受付, 1984年 8 月20日受理〕 


\section{は じめに}

血小板由来増殖因子 ${ }^{12)}$ (PDGF, platelet derived growth factor) は血栓形式時に流血中に 放出される細胞増殖因子で病態生理上血管壁の 損傷治癒過程, 動脈硬化, 各種臓器の線維化, 腫瘍細胞の転移促進に関与することが知られて (いる3)4.

ところで従来報告されてきた PDGF は塩基 性の等電点をもち, その標的細胞は線維芽細胞 などの間葉系細胞とされている。しかし，われ われはこれとまったく等電点の異なる細胞増殖 因子を血小板中に見い出し，その標的として， むしろ腫瘍細胞に特異性が強いことを知ったの で報告する。

\section{I. 方 法}

\section{1. 培養細胞}

線維芽細胞由来株として BALB/c 3T3, Swiss 3T3，SV 3T3 を用いた。 ヒト腫瘍細胞として K 562 (ヒト白血病), HeLa (子宮癌), RPMI 4788 (大腸癌) を用いた. 線維芽細胞は培養液 として 10\% ウシ胎児血清 (FCS) を含む Dulbecco's modified Eagle's medium (DMEM),
腫瘍細胞は $10 \%$ FCS を含む RPMI 1640 を用 いた。

2. 血小板 lysate の抽出法および PDGF の精製(5)6)

正常人より得られた血小板血漿を 4,000 rpm 15 分遠心後, pellet の赤血球を低浸透圧破壊し 血小板を $0.1 \%$ EDTA を含むPBS にて 3 回洗 浄した. その後，血小板 lysate は sonicator に $\tau 4^{\circ} \mathrm{C} 50$ watt 15 分超音波破砕し, 引き続い て超遠心 (100, $000 \mathrm{~g} 1$ 時間) を行ならことによ り作製し, thymidine phosphorylase 活性を 除く目的で $100^{\circ} \mathrm{C} 3$ 分熱処理して使用した。 PDGF を精製する目的で DE 52 cellulose によ るイオン交換 column chromatography を行な い(0.02 M sodium phosphate buffer, PH 7.2), その素通り分画と $0.5 \mathrm{M} \mathrm{NaCl}$ 塩濃度勾配に より溶出される吸着分画を得た。ささらカラム 等電点電気泳動 (PH 2-12) にて分析し, この 増殖活性を示す peakを Bio-Gel P-100 にて 分画した.

\section{3. 細胞増殖活性の測定法}

$1 \times 10^{5}$ 個の線維芽細胞または腫瘍細胞を 1 \% FCS を含む DMEM あるいは RPMI 1640 を 用いて，マイクロプレート中で $37^{\circ} \mathrm{C} 5 \% \mathrm{CO}_{2}$

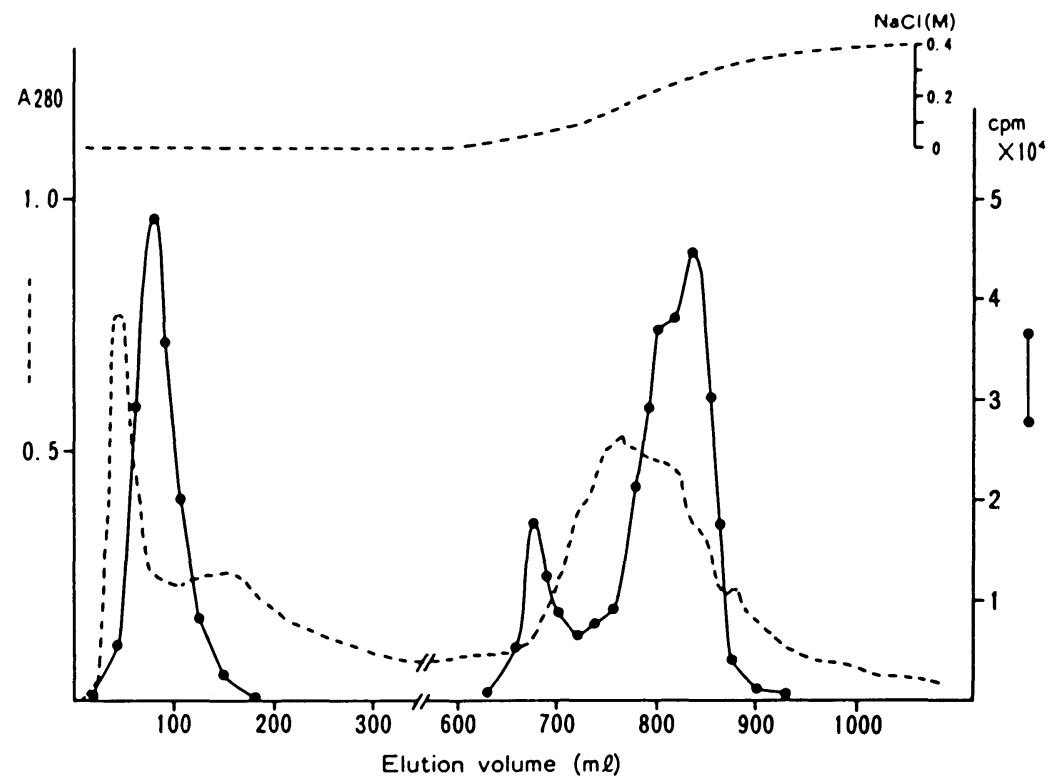

Fig. 1 DE 52 cellulose chromatogram of platelet lysate. Growth promoting activity (-๑) is represented by ${ }^{3} \mathrm{H}$-thymidine incorporation using $\mathrm{BALB} / \mathrm{c} 3 \mathrm{~T} 3$ for target cell. 


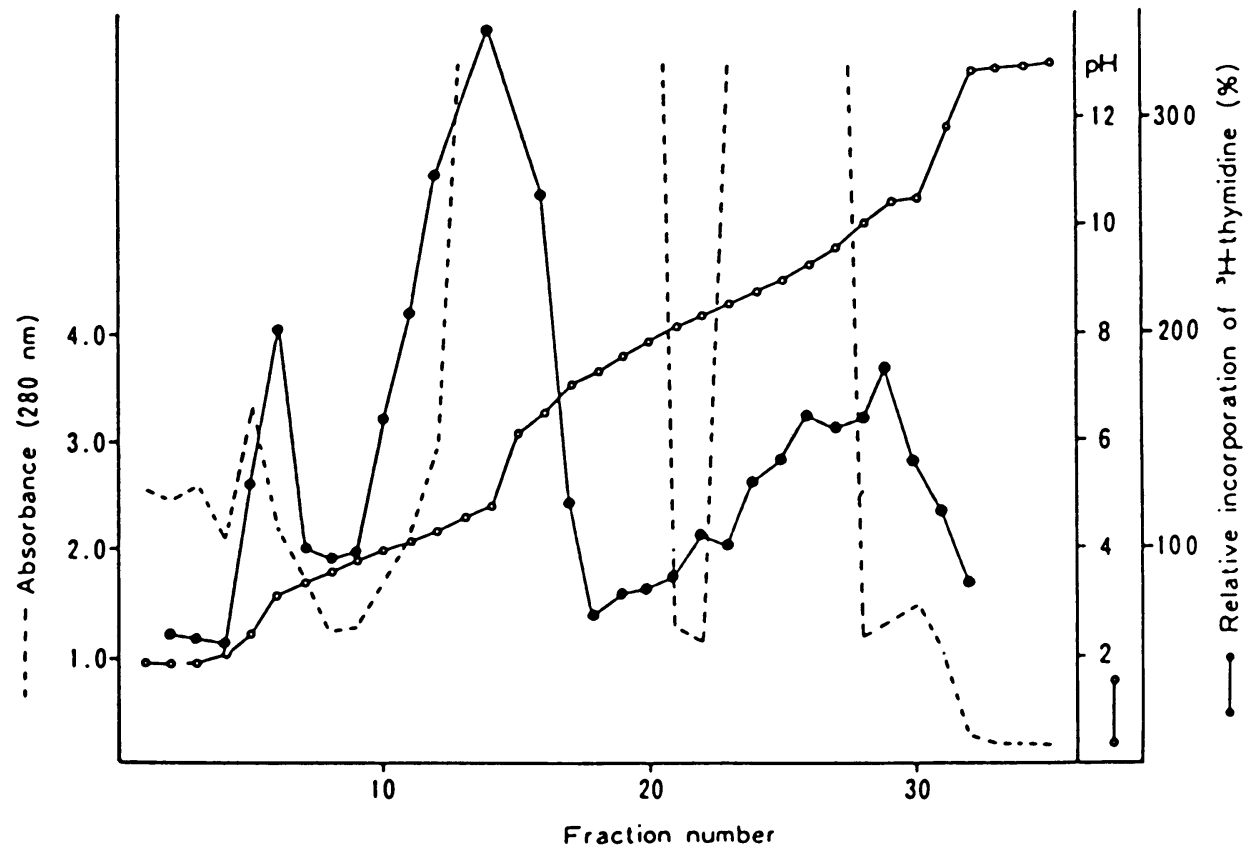

Fig. 2 Ion exchange chromatogram of platelet-derived growth factors.

Growth promoting activity (- - ) is represented as relative incorporation of ${ }^{3} \mathrm{H}$-thymidine.

Table 1 Target cell speificity of three active peaks

\begin{tabular}{llccc}
\hline & & \multicolumn{2}{c}{ Growth factors in platelet lysate } \\
\cline { 3 - 4 } Cell lines & Origin & acidic & neutral & basic \\
\hline Swiss 3T3 & mouse fibroblast & H & + & + \\
SV 3T3 & SV40 transformed & + & + & + H \\
K 562 & mouse fibroblast & & + & + \\
HeLa & Human leukemia & Ht & + & - \\
RPMI 4788 & Human uterus ca. & H & - & + \\
\hline
\end{tabular}

にてあらかじめ 24 時間培養を行った。その後 FCS 無添加培養液に交換し, 終濃度が血小板 lysate の $80 \mu \mathrm{g} / \mathrm{m} l$ に相当する部分精製 PDGF を加光 $37^{\circ} \mathrm{C} 5 \% \mathrm{CO}_{2}$ の条件にて 3-72 時間培 養し，3時間後の ${ }^{3} \mathrm{H}$-thymidine の取り込みを 測定した.

\section{4. 細胞周期同調法}

腫瘍細胞の同調培養は既報に従い thymidine 怙よび hydroxyurea の二重処理法により pre S 期に同調させ行なった7).

\section{II. 結 果}

血小板 lysate を DE 52 cellulose chromatography により分画し，その各分画について $\mathrm{BALB} / \mathrm{c}$ 3T3 を標的細胞として増殖促進活性 を調べた結果を Fig. 1 に示した. 素通り分画お よび吸着分画から合計 3 つの活性 peak を得た. さらにこれらの peak を集めカラム等電点電気 泳動にて分析したところ，それぞれ $\mathrm{pI}$ 3.1-3.5 (acidic peak), pI 6. 5-7.0 (neutral peak), pI9.2 

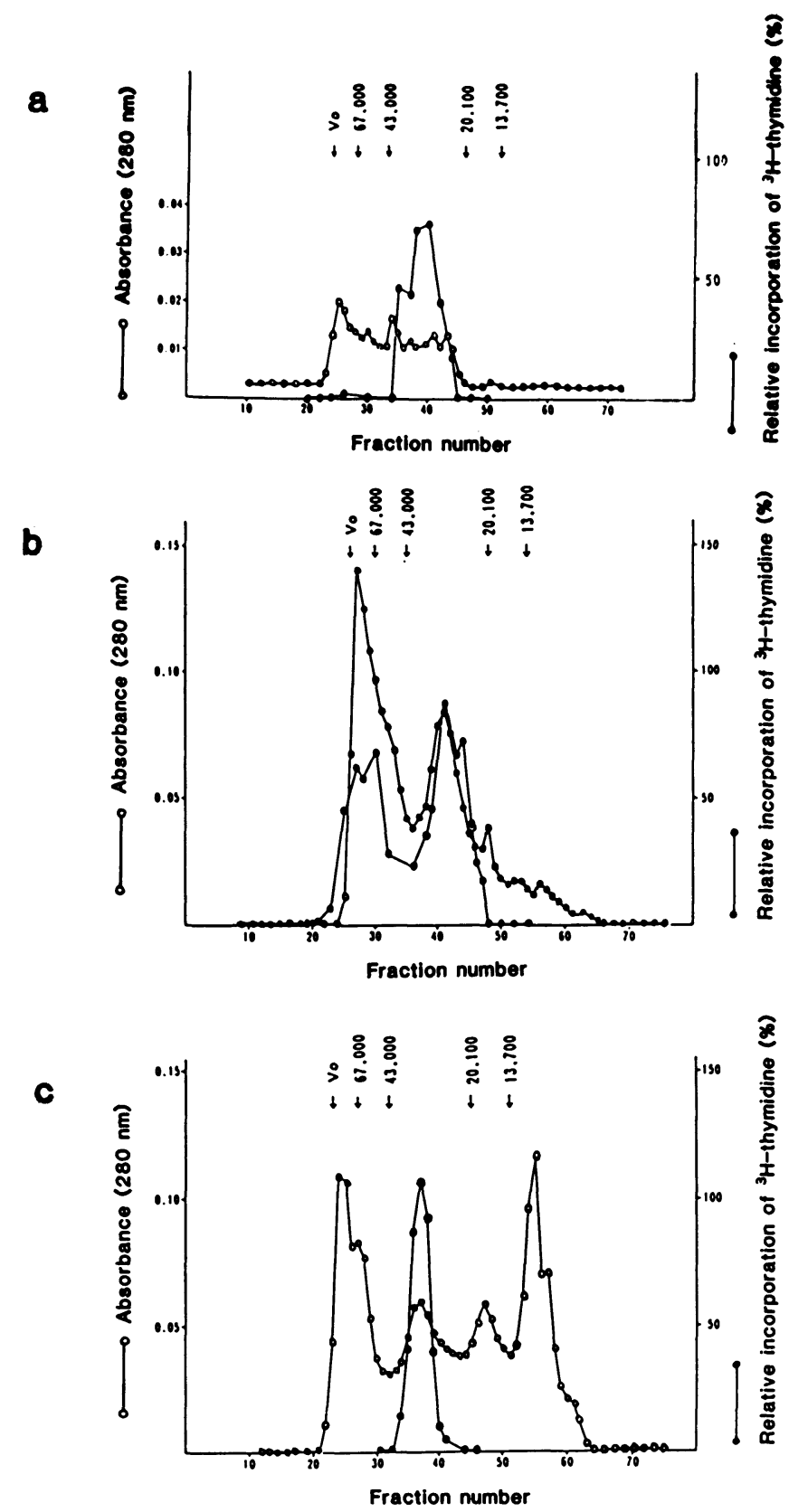

Fig. 3 BioGel P-100 chromatogram of three kinds of PDGFs separated by ion exchange chromatogram. a: acidic, b: neutral, c: basic

-10.5 (basic peak) に活性を示した（Fig. 2). さらにとれぞれの活性 peak B Bio-Gel P-100 chromatography にて分画したところ分子量は いずれも約3万であった(Fig. $3 \mathbf{a}, \mathbf{b}, \mathbf{c})$. neutral peak 飞执いては void volume 飞も増殖活性 を示す分画が得られた. カラム等電点電気泳動
のそれぞれの peak について各種培養細胞を標 的とし，増殖促進活性を検討した (Table 1). basic peak は線維芽細胞である Swiss 3T3, SV 3T3 を強く増殖させたが，腫瘍細胞株であ る K 562, HeLa, RPMI 4788 に対しては活 性がきわめて弱かった。他方 acidic peak はむ 
Tabie 2 Physicochemical properties of acidic, neutral and basic peak

(BALB/c 3T3 for target cells)

\begin{tabular}{|c|c|c|c|}
\hline \multirow{2}{*}{ Treatment } & \multicolumn{3}{|c|}{ Remaining activity ( $\%$ of control) } \\
\hline & acidic & neutral & basic \\
\hline $100^{\circ} \mathrm{C} \quad 5 \mathrm{~min}$ & 88 & 93 & 100 \\
\hline $30 \mathrm{~min}$ & 101 & - & - \\
\hline $\mathrm{pH} 3$ & 92 & 94 & 80 \\
\hline $\mathrm{pH} 10$ & 76 & 86 & 99 \\
\hline Freeze $\&$ thawing 3 times & 102 & - & 101 \\
\hline 6 times & 86 & - & - \\
\hline Trypsin digestion $(1 \mathrm{mg} / \mathrm{m} l)$ & 69 & 56 & 72 \\
\hline
\end{tabular}

しろ反対に, 腫瘍細胞を強く増殖させ, 線維芽 細胞に対しては basic peak に比べ増殖活性が 弱かった. neutral peak は線維芽細胞, 腫瘍 細胞両者に弱い増殖活性を示した. そこで， acidic peak と basic peak $の$ cell cycle phase $た$ 扣よぼす影響について比較検討した (Fig. 4). K 562 細胞を pre $\mathrm{S}$ 期に同調させ， acidic 牛 よび basic peakを plus 投与し, 増殖活性すな わち経時的 ${ }^{3} \mathrm{H}$-thymidine の取り込みを調べた ところ，その ${ }^{3} \mathrm{H}$-thymidine の取り込反 patte$\mathrm{rn}$ に差がなく, S 期の peak は 3-6 時間と同一 であった. 次に acidic peak の物理化学的性状 について neutral, basic peak と比較検討した (Table 2). この 3 種の血小板由来増殖因子は 熱・酸・アルカリ処理, 凍結融解に対してきわ めて安定であり, ともに $1 \mathrm{mg} / \mathrm{ml}$ の濃度の trypsin 処理により約 $40 \%$ の失活をみとめた.

\section{III. 考察}

Ross $^{8)}$, Antoniades $^{1)}$, Heldinn $^{2)}$ らにより報告 されている PDGF は線維芽細胞, 血管内皮細 胞などを増殖させる因子として知られている。 これは塩基性の等電点 $(\mathrm{pI}$ 10.3) をもち，その 分子量の違いから Type I (m.w. 31,000) と Type II (m.w. 28, 000) の 2 つの分子種が報告 されている ${ }^{9)}$. これらは共通の抗原性を有し, 細胞増殖活性にも差異を認めず，最近の報告で は，前者は後者が glycosylation を受けたもの とされている. 今回われわれはこれらと物理化 学的性状ならびに標的細胞特異性に拈いて異な る 2 つの新しい血小板由来増殖因子を見い出し た. それは $0.02 \mathrm{M}$ sodium phosphate, PH 7.4

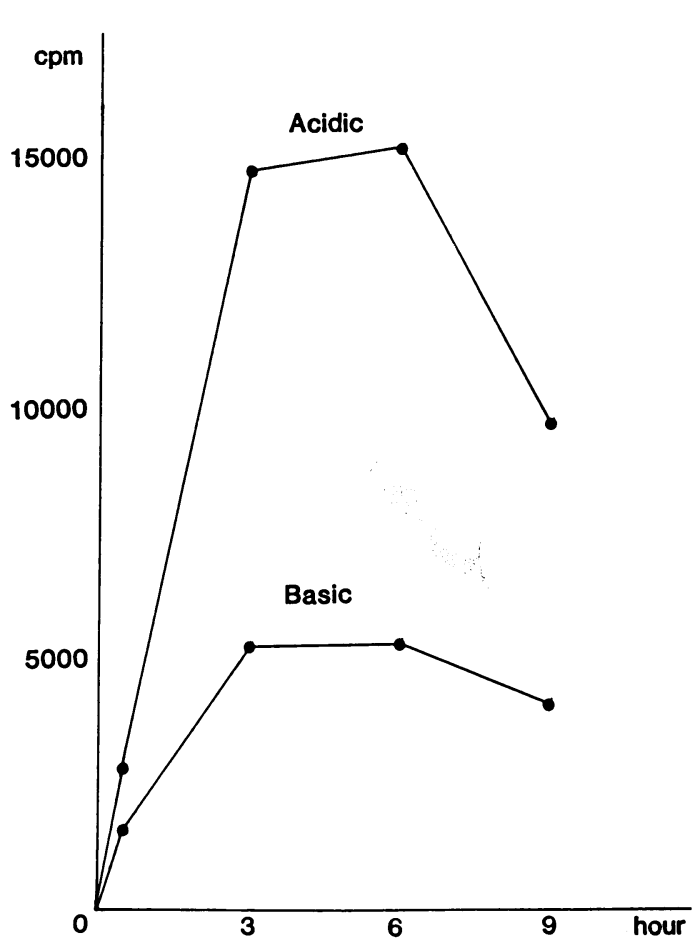

Fig. 4 Effect of acidic and basic peak to K 562 cell cycle phase.

の条件で DE 52 イオン交換カラムに吸着する 物質であり, 等電点電気泳動にて, pI 6.5-7.0 (neutral peak), pI 3.1-3.5 (acidic peak)を示 し明らかに従来より報告されている PDGF と 異なっていた，一方，DE 52 カラムクロマトグ ラフィーにて素通りする分画，すなわち basic peak は等電点, 分子量および 線維芽細胞に対 して，強い増殖活性を示すことから諸家のいら PDGF と同一のものと考光られた ${ }^{10)}$.これらの 因子の標的細胞特異性については basic peak 
が線維芽細胞由来株を強く増殖させたのに対し $て$ acidic peak は間葉系さらには上皮性由来の 人腫瘍細胞に対してきわめて強い増殖活性を示 した.ところで PDGF は cell cycle phase の $\mathrm{G}_{0}-\mathrm{G}_{1}$ 期に作用し増殖活性を示すことが知られ ている ${ }^{11)}$. そこで acidic peak について標的細 胞をK 562 とし cell cycle に扣よぼす影響を basic peak との比較において検討したところ cell cycle を特に速めるものではなかった. し たがって，この acidic peak は basic peak (PDGF）に比べてより多くの腫瘍細胞を S 期へ導 入すると考兄られる. 近年, 増殖因子のあるも のが腫瘍細胞により産出され，その腫瘍自身に 作用する (Todaro の autocrine 説) ことが報告 され(12), しかも増殖因子のいくつかが oncogene product と分子構造上さわめて類似しているこ とが知られてきた ${ }^{13)}$. PDGF についてもそのア ミノ酸構成が c-sis oncogene product である p28sis と homology のあることが明らかにさ れ14)，細胞の腫瘍化（または transformation） および腫瘍の自己増殖に重要な役割を担ってい ることが伺われる。しかし，PDGF は間葉系腫 瘍の増殖のみをうながし, 上皮性細胞には作用 しないとされている.われわれの acidic peak は間葉系腫瘍に限らず，他の K 562 (ヒト白血 病), HeLa (ヒト子宮癌), RPMI 4788 (ヒト 大腸癌）由来腫瘍細胞をも増殖させるといら性 質から，きわめて興味深い因子であると考兄ら れる。

ところで acidic peak は分子量約 3 万, heat stable $\left(100^{\circ} \mathrm{C} 30\right.$ 分) であり, 3 回の凍結融解後 も活性の低下を認めず, 物理化学的性状は, 塩 基性 PDGF と類似していた. 最近 Heldin ${ }^{15)} ら$ が CM セルロースカラムを素通りする酸性の 等電点をもつ血小板由来増殖因子を報告し，こ れは抗 PDGF 抗体と交叉免疫性を示さないこ とから，血小板中には PDGF とまったく異な った種類の増殖因子が存在することを示唆し た。また Child ${ }^{16)} ら は$ 血清中に腫瘍細胞を増殖 させる因子（transforming growth factor）を 見い出しそれらが血小板由来であろらと推定し ている.

今後われわれの acidic peak とこれらの gro- wth factor との異同について，より詳細な検 討を加える予定である。

\section{文献}

1) Antoniades, H.N., Scher, C.D. and Stiles, C.D. : Purification of human platelet-derived growth factor. Proc. Natl. Acad. Sci. U.S.A., 76; 1809 1813, 1979.

2) Heldin, C.-H., Westermark, B. and Wasterson, A.: Platelet-derived growth factor: Purification and partial characterization. Proc. Natl. Acad. Sci. U.S.A., 76; 3722 3726, 1979.

3) Harker, L.A., Ross, R., Slichter, S.J. and Scott, C.R. : Homocystine-induced arteriosclerosis: The role of endothelial cell injury and platelet response in its genesis. J. Clin. Invest., 58; 731 741, 1976.

4) Ross, R. and Glemset, J.A. : The patogenesis of artheriosclerosis. (part 1 and 2), $\mathrm{N}$. Engl. J. Med., 295; 369 377, 420 425, 1976.

5）新津洋司郎, 茂木良弘, 石垣聖史, 高後 裕, 石井 徹, 漆崎一朗：血小板由来増殖因子によ る癌細胞增殖作用の特性 一線維芽細胞との比 較一. 血液と脈管, 13；309～313，1982.

6）新津洋司郎, 茂木良弘, 越田吉一, 石垣聖史, 石井 徹, 熊井良司, 高後 裕, 泩崎一朗 : 血 小板由来の細胞増殖因子の 特 性 と腫瘍細胞の 増殖に扣よぼす作用. 血液と脈管, 14：481〜 484, 1983.

7）日本組織培養学会編：組織培養の技術. p. 6266, 朝倉書店, 1982.

8) Ross, R., Glemset, J., Kariya, B. and Harker, L. : A platelet-dependent serum factor that stimulates the proliferation of arterial smooth muscle cells in vitro. Proc. Natl. Acad. Sci. U.S.A., 71; 1207 1210, 1974.

9) Deuel, T.F., Huang, J.S., Proffitt, R.T., Baenziger, J.U., Chang, D. and Kennedy, B.B. : Purification and resolution into active protein fractions. J. Biol. Chem., 256; 8896 $\sim 8899,1981$.

10) Heldin, C. -H., Westermark, B. and Westerson, A.: Specific receptor for platelet derived growth factor on cells derived from 
connective tissue and glia. Proc. Natl. Acad. Sci. U.S.A., 78; 3664 3668, 1981.

11) Scher, C.D., Shepard, R.C., Antoniades, H. N. and Stiles, C.D. : Platelet-derived growth factor and the regulation of the mammalian fibroblast cell cycle. Biochem. Biophys. Acta, 560; 217 241, 1979.

12) Sporn, M.B. and Todaro, G.J. : Autocrine secretion and malignant transformation of cells. N. Engl. J. Med., 303; 878 880, 1980.

13) Gaubin, G., Goldman, D.F., Luce, J., Nerman, P.E. and Cooper, G.M. : Molecular cloning and nucleotide sequence of a transforming gene detected by transfection of chicken B-cell lymphoma DNA. Nature, 302; 114 119, 1983.

14) Waterfield, M.D., Scrace, G.T., Whittle, N.,
Stroobant, P., Johnsson, A., Wasteson, A., Westermark, B., Heldin, C.H., Huang, J.S. and Deuel, T.F.: Platelet-derived growth factor is structurally related to the putative transforming protein $28^{\text {sis }}$ of simian sarcoma virus. Nature, 304; 35 39, 1983.

15) Heldin, C.-H., Wasterson, A. and Westermark, B. : Partial purification and characterization of platelet factors stimulating the multiplication of normal human glial cells. Exp. Cell. Res., 109; 429 437, 1977.

16) Child, C.B., Proper, J.A., Tucker, R.F. and Moses, H.L. : Serum contains a plateletderived transforming growth factor. Proc. Natl. Acad. Sci. U.S.A., 79; 5312 5316, 9182 .

\section{一日常診療の落し穴と安全性を示す! \\ 小児の医療事故と救急処置}

編集 日本大学小児科教授 馬場一雄 専門医50氏分担執筆 B 5 判 337頁 図52 表|20 定価9,800円(干350円)

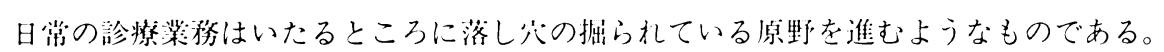
どんなに父をつけて少いても，落し分に落ち込まないですむ保䚀はない。しかし，どこに

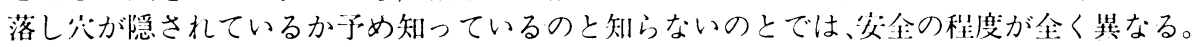

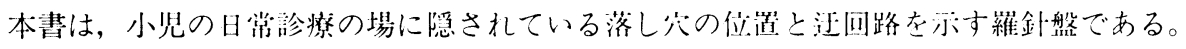

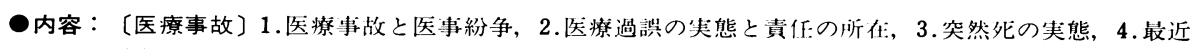

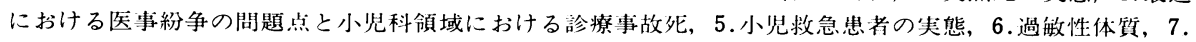
臨床検查に伴う事故とその対策 (その1)，8. 臨床検査に伴う事故とその対策(その 2 ), 9. 注射に伴う事故 とその对策, 10 . 輸血に伴う事故とその対策, 11 . 輸液に伴う事故とその対策, 12 . 交換輸血に伴う事故と その対策, 13. 麻酔に伴う事故とその対策, 14. 小児外科手術に伴う事故とその対策, 15 . 放射線照射に伴 j障害とその対策, 16 . 看濩に伴う事故とその対策, 〔救急処置〕1. 急発怔状と忍急対策, 2 . 救急疾患と腎 急治療, 3.救急医療。 